\title{
The Problem of Sociability after Hobbes : Pufendorf and Locke on the Politics of Recognition
}

\section{Haara, Heikki \\ De Gruyter Oldenbourg \\ 2020-08-24}

Haara , H \& Stuart-Buttle , T 2020 , The Problem of Sociability after Hobbes : Pufendorf and Locke on the Politics of Recognition . in H Haara, K Stapelbroek \& M Immanen (eds), Passions, Politics and the Limits of Society . , 9 , Helsinki Yearbook of Intellectual History , vol. 1 , De Gruyter Oldenbourg, Berlin , pp. 177-194 . https://doi.org/10.1515/9783110679861-011

http://hdl.handle.net/10138/325063

https://doi.org/10.1515/9783110679861-011

acceptedVersion

Downloaded from Helda, University of Helsinki institutional repository.

This is an electronic reprint of the original article.

This reprint may differ from the original in pagination and typographic detail.

Please cite the original version. 
Pre-proof copy for circulation: please cite the published version at

https://www.degruyter.com/view/book/9783110679861/10.1515/9783110679861-011.xml

DOI: https://doi.org/10.1515/9783110679861-011

\title{
The Problem of Sociability after Hobbes: Pufendorf and Locke on the Politics of Recognition
}

\author{
Heikki Haara \& Tim Stuart-Buttle
}

Thomas Hobbes's place in the history of modern political thought is somewhat curious. Hobbes is perhaps the most 'political' of all political philosophers, focusing as he did primarily on the origins, nature, and authority of the state as an "artificial person". ${ }^{1}$ Yet the period ca.1650-1800 witnessed a notable expansion of the scope of the political, with an increased attentiveness to how broader social and economic forces exert themselves on individuals in such ways as to render them susceptible to 'government', understood in a Foucauldian sense as "the conduct of conduct". ${ }^{2}$ As Foucault argued, sociability (socialitê - how individuals coexist with one another - became a new matter to "police" from the seventeenth century onwards. ${ }^{3}$ Hobbes is implicated in this turn away from a narrow focus on the state and its monopolization of disciplinary power, because to a considerable extent it was undertaken to confront a question that Hobbes had himself made pressing - but one to which his own political theory was held to offer an inadequate solution. ${ }^{4}$ This was the problem, in Kant's memorable formulation, of "unsocial sociability". ${ }^{5}$ By what means might human beings, with all their antisocial characteristics, be induced to exercise the kinds of

\footnotetext{
${ }^{1}$ Quentin Skinner, "Hobbes and the Purely Artificial Person of the State," Journal of Political Philosophy 7 (1999): 1-29.

${ }^{2}$ Michel Foucault, The Foucault Effect: Studies in Governmentality, ed. Graham Burchill, Colin Gordon, and Peter Miller (Chicago: University of Chicago Press, 1991), 48.

${ }^{3}$ Michel Foucault, Security, Territory and Population: Lectures at the Collège de France, 1977-1978, trans. Graham Burchell and ed. Michael Senellart (New York: Palgrave Macmillan, 2007), 326.

4 John Robertson, "Sacred History and Political Thought: Neopolitan Responses to the Problem of Sociability," Historical Journal 56 (2013): 1-6.

5 Jerome B. Schneewind, "Good Out of Evil: Kant and the Idea of Unsocial Sociability," in Kant's Idea for a Universal History with a Cosmopolitan Aim: A Critical Guide, eds. Amélie Oksenberg Rorty, and James Schmidt (Cambridge: Cambridge University Press, 2009), 94-111.
} 
self-control required to make large-scale, peaceful, and even prosperous societies possible? ${ }^{6} \mathrm{Few}$ eighteenth-century philosophers exhibited sustained interest in Hobbes's theory of the state; but their engagement with the problem of sociability to which that theory was intended as a solution only "intensified and ramified" as the decades passed, as the example of Kant illustrates.

A notable characteristic of much eighteenth-century moral and political philosophy is its attentiveness to our radical sensitivity to the evaluative judgments of observing others. ${ }^{8}$ Subjectivity is, on this line of thinking, the product of intersubjective processes to which we are all susceptible because of our deep desire for recognition. Political, critical and moral theorists have in recent years drawn attention to recognition as a fundamental human need, essential to our well-being, and to misrecognition as symptomatic of unjust societies and generative of social conflict and strife. Such theorists agree that recognition first acquired prominence in eighteenth-century philosophy whether in the writings of Hegel or Rousseau. ${ }^{9}$ This is, however, mistaken: for all that they may have done so in unusually powerful and innovative ways, Rousseau and Hegel were intervening in an ongoing conversation about the desire for recognition and its implications that they did not initiate. Insofar as they, like Kant, understood this conversation to be a part of a broader debate over the problem of sociability, its terms were set by Hobbes. As István Hont observes, it was Hobbes who first claimed that the fundamental problems of politics all stem "from the politics of recognition". ${ }^{10}$ As much recent scholarship has emphasised, sociability was a problem for Hobbes in large part because the desire for recognition generated a further desire: for society - the realization of which it nonetheless frustrated. ${ }^{11}$

If one accepts Hobbes's interpretation of the desire for esteem as by its very nature generative only of mutual non-recognition and conflict, then the problem of sociability appears susceptible only of Hobbes's political solution - one reliant upon both fear of punishment and the

\footnotetext{
${ }^{6}$ For a conspectus of the scholarship on the post-Hobbesian sociability debate, see Eva Piirimäe and Alexander Schmidt, "Introduction: Between Morality and Anthropology - Sociability in Enlightenment Thought," History of European Ideas 41 (2015): 571-588.

7 Robertson, "Sacred History," 6.

8 Arthur Lovejoy, Reflections on Human Nature (Baltimore: The Johns Hopkins University Press, 1961).

${ }_{9}$ Axel Honneth, The Struggle for Recognition: The Moral Grammar of Social Conflicts, trans. Joel Anderson (Cambridge: Polity Press, 1995); Frederick Neuhouser, Rousseau's Theodicy of Self-Love: Evil, Rationality, and the Drive for Recognition (Oxford: Oxford University Press, 2008). For the pre-Hegelian history of recognition, see now Axel Honneth, Anerkennung: Eine europäische Ideensgeschichte (Berlin: Suhrkamp, 2018); and Risto Saarinen, Recognition and Religion: A Historical and Systematic Study (Oxford: Oxford University Press, 2016).

${ }^{10}$ István Hont, Politics in Commercial Society: Jean-Jacques Rousseau and Adam Smith, eds. Béla Kapossay and Michael Sonenscher (Cambridge, MA: Harvard University Press, 2015), 11-12.

11 Gabriella Slomp, Thomas Hobbes and the Political Philosopby of Glory (Basingstoke: Palgrave Macmillan, 2000); Julia E. Cooper, "Vainglory, Modesty, and Political Agency in the Political Theory of Thomas Hobbes," The Review of Politics 72 (2010): 241-269; Paul Sagar, The Opinion of Mankind: Sociability and the Theory of the State from Hobbes to Smith (Princeton, NJ: Princeton University Press, 2018), 27-66.
} 
political re-education of subjects. ${ }^{12}$ If, however, the desire for esteem opens us up to the evaluative opinions of our neighbours in such ways as induce us to exercise the self-control required for sociable living, then the production of disciplined and law-abiding citizens is not (and cannot be) the exclusive preserve and achievement of state politics. In what follows, we illustrate how two of Hobbes's earliest critics, who (like Hobbes) operated within the framework of Protestant natural jurisprudence - Samuel Pufendorf and John Locke - challenged his interpretation of the consequences of the desire for esteem in precisely this way. ${ }^{13}$ While all three philosophers agreed that the desire for recognition makes men susceptible to (re-)education, Pufendorf and Locke emphasised that the socio-psychological processes that lead people to adopt the norms of sociable behaviour are not directly controlled by the sovereign. Both offered alternative explanations of how human beings become sociable, morally accountable creatures by living together in society, without invoking Hobbes's "mortal God" or rehabilitating the doctrine of natural human benevolence and sociability. The focus on esteem and recognition in post-Hobbesian natural jurisprudence has, until recently, been ignored by scholars. ${ }^{14}$ In what follows, we will recover the intellectual framework in which the questions of recognition and non-recognition were initially formulated in post-Hobbesian natural law jurisprudence. This shift of focus will reveal the significant continuities between the responses to the problem of sociability generated from within Protestant natural jurisprudence, and those developed by eighteenth-century philosophers from Rousseau and Smith to Kant and Hegel.

\section{Hobbes: Recognition, Inequality, and the Problem of Sociability}

\footnotetext{
12 For the place of both fear and education in Hobbes's solution to the problems generated by the desire for recognition, see Eva Odzuck, "War by Other Means? Incentives for Power Seekers in Thomas Hobbes's Political Philosophy," Review of Politics 81 (2019): 21-46.

${ }^{13}$ Building on Heikki Haara and Tim Stuart-Buttle, "Beyond Justice: Pufendorf and Locke on the Desire for Esteem," Political Theory 47 (2019): 699-723.

${ }^{14}$ For notable exceptions see James Tully "Governing Conduct", in Conscience and Casuistry in Early Modern Europe, ed. Edmund Leites (Cambridge: Cambridge University Press, 1988), 12-71; Kari Saastamoinen, "Pufendorf on Natural Equality, Human Dignity, and Self-Esteem," Journal of the History of Ideas 71 (2010): 39-62; Tim Stuart-Buttle, “"A Burthen Too Heavy for Humane Sufferance': Locke on Reputation”, History of Political Thought 38 (2017): 644-680; Heikki Haara and Aino Lahdenranta, "Smithian Sentimentalism Anticipated: Pufendorf on the Desire for Esteem and Moral Conduct", Journal of Scottish Philosophy 16 (2018): 19-37; Heikki Haara, Pufendorf's Theory of Sociability: Passions, Habits and Social Order (Cham: Springer, 2018), 99-136; Haara and Stuart-Buttle, "Beyond Justice"; Tim Stuart-Buttle, From Moral Theology to Moral Philosophy: Cicero and Visions of Humanity from Locke to Hume (Oxford: Oxford University Press, 2019); Hannah Dawson, "The Normativity of Nature in Pufendorf and Locke," Historical Journal, Online First (2019).
} 
In his first published foray into political philosophy, Hobbes launched a forthright assault on Aristotle's theory of natural human sociability which, he claimed, had misled all subsequent "writers on public Affairs". ${ }^{15}$ Aristotle's conclusion that "the Human is an animal born fit [aptum natum] for

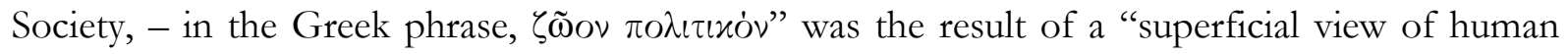
nature": one that misconstrued "the causes why men seek each other's company and enjoy associating with each other". ${ }^{16}$ Importantly, Hobbes accepted two constitutive elements of Aristotle's theory: that men by nature do desire society with others; and that they do so to secure goods that are not confined to those required for self-preservation and physical well-being. Yet Hobbes argued that Aristotle's claim that "the human being is a political animal" by nature (zoon politikon) was unwarranted, and predicated on a fundamental misunderstanding of the "Good" of "the mind" that leads men to seek company. ${ }^{17}$ On Hobbes's interpretation, Aristotle assumed that it was a natural love of others - a desire for friendship - that gives rise to society, and generates relationships characterized by reciprocity and an acknowledgement of mutual equality. Political society, in turn, allows men to consolidate these bonds of fellowship in the polis. ${ }^{18}$ For Hobbes, in contrast, society "is a product of love of self, not of love of friends". The "good" of the mind we seek in society is not friendship, but "reputation and honour" - which is a form of power. All mental pleasure, Hobbes argued, "is either Glory (or a good opinion of oneself), or ultimately relates to glory". ${ }^{19}$

Friendship is predicated upon an assumption of equality by the parties involved, and it is theoretically available to all. If, as Hobbes held Aristotle to maintain, "man naturally loved his fellow man, there is no reason why everyone would not love everyone equally as equally men". Yet it is evident that, in practice, individuals "seek the company of men whose society is more prestigious and useful to him than to others". This proves, Hobbes argued, that "what we are primarily after" from others is the mental good of "honour", along with the satisfaction of our "sensual" pleasures. Unlike friendship, "honour" assumes inequality between men and is by definition not available to all. It is a positional good, which "is nothing if everyone has it, since it

\footnotetext{
${ }^{15}$ Here Hobbes underplayed the nuance of medieval and early-modern discussions of sociability: see Annabel Brett, Changes of State: Nature and the Limits of the City in Early Modern Natural Law (Princeton, NJ: Princeton University Press, 2011).

${ }^{16}$ Thomas, Hobbes, On the Citizen, ed. Richard Tuck and trans. Michael Silverthorne (Cambridge: Cambridge University Press, 1998), 1.2.

${ }^{17}$ Hobbes, On the Citizen, 1.2; Aristotle, Nichomachean Ethics, IX.9, 1169b16-23; Aristotle, Politics, I.2, $1253 \mathrm{a} 3$.

${ }_{18}$ Nicholas Gooding and Kinch Hoekstra argue that Hobbes took issue primarily with Aristotle's theory of friendship in the Nichomachean Ethics (Books VIII-IX), rather than with his account of man as zoon politicon in the Politics: "Hobbes and Aristotle on the Foundation of Political Science," in Hobbes's On the Citizen: A Critical Guide, eds. Robin Douglass and Johan Olsthoorn (Cambridge: Cambridge University Press, 2019), 31-50.

${ }^{19}$ Hobbes, On the Citizen, 1.2.
} 
consists in comparison and pre-eminence" ${ }^{20}$ Recognition-seeking is, it follows, a zero-sum game. It stimulates competition and conflict and gives rise to relationships characterized by dominion and subjugation - by flattery, not friendship. ${ }^{21}$ By substituting the desire for recognition for Aristotle's natural love of others (philia), Hobbes was able to show that the desire that leads us to seek society necessarily precludes its realization. Unlike in The Elements of Law and De cive, in Leviathan Hobbes does not explicitly claim that glory is the most foundational human passion, and maintains that only some individuals (rather than all) are glory-seekers. Nevertheless, even in Leviathan the problems generated by glory-seeking underpin Hobbes's claims regarding the necessity of the sovereign state for peaceful cooperation, mutual trust and sociability. ${ }^{22}$ The competition for recognition, rather than for scarce material resources is the most important cause of quarrel in mankind's natural condition, as prideful individuals endeavour to extort a good from others (esteem) that they are unwilling to reciprocate. ${ }^{23}$ Every man desires affirmation of their value from others - even if, due to temperamental differences, this desire is stronger in some (the proud) than others (the more modest). Yet every man considers himself wiser than others - which ironically "proveth rather that men are in that point equall, rather than unequall" - and thus craves an affirmation of his superiority that others are disinclined to offer (unless coerced to do so). ${ }^{24}$

Society relies, as a condition of possibility, upon its members' mutual acknowledgement of their natural equality as men: equality is for Hobbes a political, rather than a physical, metaphysical or ontological imperative. ${ }^{25}$ In their natural condition, (some) men's pride precludes them from this act, thereby generating a "contest for dominion", whereas "it is necessary for the obtaining of peace" that all members of a community "be esteemed as equal" (or "accounted by nature equal to one another') ${ }^{26}$ Only thus will they recognize their obligation to play by the same rules as everyone else. In their immiserated natural condition, recognition-seeking generates unanimity on one point alone: that a superior authority is required, to whose laws every individual recognizes himself beholden. Only “men's mutual fear", stimulated primarily by the competition and violence

\footnotetext{
20 Ibid.

${ }^{21}$ Daniel J. Kapust, That Glib and Oily Art: Flattery and the History of Political Thought (Cambridge: Cambridge University Press, 2018), 64-95.

${ }^{22}$ For differences and continuities in Hobbes's treatment of glory across his works, see Gabriella Slomp, "Hobbes on Glory and Civil Strife," in The Cambridge Companion to Hobbes's Leviathan, ed. Patricia Springborg (Cambridge: Cambridge University Press, 2007), 181-198.

23 Thomas Hobbes, Leviathan, ed. Noel Malcolm, 3 vols. (Oxford: Oxford University Press, 2012), Part 1. Chap. 13; cf. 1.17, p. 258; see Arish Abizadeh, "Hobbes on the Causes of War: A Disagreement Theory," American Political Science Review 105 (2011): 298-315.

${ }^{24}$ Hobbes, Leviathan, 1.13, 188; cf. On the Citizen, 1.3

${ }_{25}$ Kinch Hoekstra, "Hobbesian Equality," in Hobbes Today: Insights for the 21 ${ }^{\text {st }}$ Century, ed. S. A. Lloyd (Cambridge: Cambridge University Press, 2012), 76-112.

${ }^{26}$ Hobbes, On the Citizen, 3.13.
} 
generated by recognition-seeking, and not Aristotle's alleged "mutual human benevolence" can provide the foundation for any "large and lasting society". ${ }^{27}$ The Gordian Knot resulting from the opposition between pride and equality is only cut once men promise, one to another, to obey a superior (the Leviathan), to whose authority they are all equally subject. ${ }^{28}$

The awful "mortal God" instils fear in those in whom the desire for recognition is strongest, thereby emancipating the more modest from their fear of the vainglorious. By means of the penalties of civil law and the monopolisation of the apparatuses of socialization (the pulpit, universities and printing press), the sovereign constrains and educates subjects to acknowledge their natural equality as men. As citizens, some individuals might legitimately lay claim to honour from others. Yet Hobbes laboured the point - and his sovereign is required to labour the point that this claim to esteem it is not theirs by right on account of their superior endowments or achievements. It is enjoyed solely at the free grace and discretion of the sovereign, the fount of all honour in the commonwealth. As king of the children of pride, Hobbes's Leviathan must carefully superintend the economy of esteem in the commonwealth, with an extent of vision that enables it to monitor the "signes of respect" men "give to one another" even in "private meetings". ${ }^{29}$ Unlike his celestial archetype, the sovereign need not be able to read men's hearts; but like the prisoners of Bentham's Panopticon, his subjects must always feel his eyes upon them, and regulate their every expression of esteem (for themselves, and for others) according to his will.

On Hobbes's interpretation, then, the desire for recognition as an expression of pride precludes men in their natural condition from acknowledging their mutual equality, and their mutual accountability to a shared law. This law is the law of nature, given to mankind by their Creator and promulgating precepts that include the duty laid out most clearly in the Gospel: to love one's neighbour as oneself. Hobbes argued that recognition-seekers, desirous of dominion over others, refused to acknowledge the reciprocal duties inscribed in natural law. Consequently, the more "modest" and "tractable" were only obligated to adhere to natural law "in foro interno" - "he that endeavoureth their performance, fulfilleth them" - but "in foro externo, that is, to putting them in act, not alwayes". To act on such precepts might render the "modest" man "a prey to others" who refused to do likewise, and "procure his own certaine ruine" - in contravention of the fundamental duty under natural law of self-preservation. ${ }^{30}$ It followed that "the Lawes of Nature [...], in the condition of meer Nature [...], are not properly Lawes", but merely "qualities" that if

\footnotetext{
27 Ibid., 1.2 .

${ }^{28}$ Hobbes, Leviathan, 1.17; see Joshua Mitchell, "Hobbes and the Equality of the All under the One," Political Theory 21 (1993): 78-100.

${ }^{29}$ Hobbes, Leviathan 2.18, 276-80.

${ }^{30}$ Ibid., 1.15, 240.
} 
followed by all would "dispose men to peace, and to obedience". ${ }^{31}$ Prior to their promulgation by the sovereign in civil law, natural law lacks the sanctions of reward and punishment that make compliance in the interest of every individual.

But might the desire for recognition, if interpreted in a different light, facilitate rather than preclude men's acknowledgement in foro interno of their reciprocal duties under natural law? Might esteem and contempt not be considered as sanctions that also incentivize compliance in foro externo, and thus make natural law truly a law in our pre-political condition? Hobbes canvassed both possibilities, only to discount them for reasons already discussed: the "Desire of Praise, disposeth [Men] to laudable actions, such as please them whose judgment they value". ${ }^{32}$ We only "value" the "judgment" of those more powerful than ourselves - and not the judgment of all mankind equally. ${ }^{33}$ This means that our desire for esteem induces us to act in ways that are deemed good by particular individuals because such actions conduce to their personal benefit, rather than to the mutual benefit of all members of our community. Consequently, the sanctions of praise and contempt might only incite a competition to excel one another in the performance of our reciprocal moral duties - "the most noble and profitable contention possible" - within a commonwealth, in which the sovereign determines what is estimable and contemptible. ${ }^{34}$ Even here, however, there is no guarantee that the sanctions of praise and contempt will reliably enforce the precepts of natural law. The sovereign might legitimately command us to honour those who, in our view, signally fail to embody these precepts in their conduct and character (this might include the deity, if the sovereign is not a Christian). ${ }^{35}$ The price of peace, and a necessary condition for the realization of sociability, might be hypocrisy: professing our esteem for those for whom, in secret, we have nothing but contempt. ${ }^{36}$

\section{Pufendorf and Locke: Esteem, Interdependence and Sociability}

The desire for others' esteem occupies a central role in the accounts of human motivation offered by Pufendorf and Locke. Pufendorf's aim was not to articulate a comprehensive account of human psychology but to demonstrate and systematize the norms and institutions that natural law demands. Therefore, his reflections on the desire for esteem are found scattered throughout his

\footnotetext{
31 Ibid., 2.26, 418.

32 Ibid., 1.11, 152: italics added.

33 Ibid., 1.10, 142.

34 Ibid., 1.11, 154.

35 Ibid., 1.16, 272.

${ }^{36}$ For Hobbes and hypocrisy see David Runciman, Political Hypocrisy: The Mask of Power, from Hobbes to Orwell and Beyond (Princeton, NJ: Princeton University Press, 2008), 16-44.
} 
works (most signifigantly, in the monumental De jure naturae et gentium (1672)). With the notable exception of Kari Saastamoinen, scholars have overlooked Pufendorf's analysis of how esteemseeking and esteem-giving may lead people to adopt the norms of sociability. ${ }^{37}$ Locke's explanation of the cognitive and behavioural implications of the desire for esteem is at once more systematic and comprehensive, and his rich private manuscripts offer us privileged access to the development of his thinking on this question. ${ }^{38} \mathrm{~A}$ number of commentators have emphasized Locke's interest in how the desire for recognition shapes our actions and opinions. They have, however, either assumed that Locke considers this to be a bad thing - custom and opinion lead us away from the dictates of reason and natural law - or focused upon it to show that the liberalism bequeathed to us by Locke requires a social conformity that bleaches us of spontaneity, moral autonomy and subjectivity. ${ }^{39}$ A consideration of Pufendorf's and Locke's interpretations of the desire for esteem as engaging critically with Hobbes's theory yields rather different insights. For both philosophers, as indeed for Hobbes, this desire opens individuals up to the evaluative judgments of their neighbours in ways that might potentially be positive or negative, depending on the criteria we use to evaluate merit and worth.

Although their proximity to Hobbes is contested, Pufendorf and Locke both accepted many of his fundamental presuppositions about human nature. In seventeenth-century Europe, no one focused more on the nature, origins and sustainability of sociability in large societies than Pufendorf. Pufendorf assumes in man a natural inclination for society (appetitus societatis); but he denies that this prompts them to establish civil society, because man can satisfy this appetite in smaller, pre-political communities "by the friendship whereby he is joined to his equals". ${ }^{40}$ Although nature has "established a general sort of friendship between men", people enter society in search of honour and advantage. ${ }^{41}$ Moreover, as had Hobbes, Pufendorf observed that the "struggle for honour and dignity" is unique to human beings, and stimulates an "envy, rivalry and hatred" that potentially leads them to transgress even the clearest dictates of natural law (not

\footnotetext{
${ }^{37}$ Kari Saastamoinen, The Morality of the Fallen Man: Samuel Pufendorf on Natural Law (Helsinki: Societas Historica Finlandiae, 1995), 149-158. For Pufendorf's analysis of the reactive attitude of resentment if someone questions our status as a human being, see Saastamoinen, "Pufendorf on Natural Equality," 55-62. For more recent analysis of the desire for esteem in Pufendorf's theory of sociability, see Haara, Pufendorf's Theory of Sociability, 99-136.

${ }^{38}$ For extensive discussion of the content of those manuscripts see Stuart-Buttle, "A Burthen".

${ }^{39}$ For the former approach, see Ruth Grant, "John Locke on Custom’s Power and Reason's Authority,” Review of Politics 74 (2012): 607-29. For the latter, Foucauldian reading see Tully, "Governing Conduct”; and Uday Singh Mehta, The Anxiety of Freedom: Imagination and Individuality in Locke's Political Thought (Ithaca, NY: Cornell University Press, 1992).

40 Samuel Pufendorf, De jure naturae et gentium, ed. Frank Böhling (Berlin: Akademie Verlag, 2008), 7.1.3/ Samuel Pufendorf, The Political Writings of Samuel Pufendorf, trans. Michael J. Seidler and ed. Craig L. Carr (New York: Oxford University Press, 1994), 203-4. The original Latin text is cited first, separated by a forward slash from the translation. ${ }^{41}$ Pufendorf, De jure naturae et gentium 2.3.18 (our translation).
} 
least that of sociality). ${ }^{42}$ In a similar vein, Locke routinely denounced "Pride and Ambition" as generative of "Covetousness", "Rapine", "Discord" and "Contention". ${ }^{43}$ Neither denied the Augustinian insight, developed by Hobbes, that pride gives rise to a violent "lust for mastery" [dominandi libido dominatur]. ${ }^{44}$ As Locke observed, none of God's other "Creatures are half so wilful and proud, or half so desirous to be Masters of themselves and others, as Man". ${ }^{45}$ Thus animated by wilful self-love, Pufendorf and Locke agreed with Hobbes that there could be no "Peace without Subjection": the laws of nature required for peace and sociability, and enjoining the reciprocal duties of justice and social virtue, are in many respects "contrary to our natural Passions, that carry us to Partiality, Pride, Revenge, and the like". ${ }^{46}$ It was evident to Locke as early as 1659 that if every man were left at liberty to guide his actions according to his own will (or "private morals"), sociable living would be impossible. ${ }^{47}$ In An Essay concerning Human Understanding (1689), Locke returned to this theme: "Men's Appetites, if left to their full swing" would "carry Men to the over-turning of all Morality" ${ }^{48}$ For sociability to be realized, Pufendorf and Locke agreed that an external constraint (law) was required to bridle the recalcitrant passions that otherwise directed men's wills and brought them into conflict. Only thus might mankind live as God decreed that they ought: in peace and mutual fellowship.

While both Pufendorf and Locke recognized that sociability requires obedience to political authority and the rules of justice it promulgates and enforces, they denied that Hobbes's (political) solution was adequate to address the problem that he had identified. The civil law, enforced by civil sanctions, might constrain men to refrain from harming one another, but it could not incentivize them to perform the reciprocal duties of social morality that give rise to the deeper ties of affection and kinship upon which social life depends. Like Hobbes, Pufendorf argues that the origin of political society "lay not in the mutual good-will of men, but in their mutual fear". Moreover, like Hobbes, he did not think that men are turned into social and political animals merely through political coercion and the fear of punishment. ${ }^{49}$ After the establishment of civil society,

\footnotetext{
42 Ibid. 7.2.4/ Samuel Pufendorf Of the Law of Nature and Nations, trans. Charles H. Oldfather and William A. Oldfather (Oxford: Clarendon Press, 1934), 969.

${ }^{43}$ John Locke, A Letter concerning Toleration, ed. Mark Goldie (Indianapolis, IN: Liberty Fund, 2010), 11, $26,40$.

44 Augustine of Hippo, The City of God against the Pagans, trans. Robert W. Dyson (Cambridge: Cambridge University Press, 1988), Preface, 3.

45 John Locke, Some Thoughts concerning Education, ed. John W. Yolton and Jean S. Yolton (Oxford: Clarendon Press, 1989), \35, 139.

46 Hobbes, Leviathan, 2.17, 254-6.

${ }^{47}$ Locke to William Godolphin, Aug. 1659, in The Correspondence of John Locke, ed. E.S. de Beer, 8 vols. (Oxford: Clarendon Press, 1976-89), i, 64-6.

48 John Locke, An Essay concerning Human Understanding, ed. Peter H. Nidditch (Oxford: Clarendon Press, 1975), 1.3.13.

49 Pufendorf, De jure naturae et gentium/ Of the Law of Nature and Nations, 214. For Hobbes's views on education, see S. A. Lloyd, "Coercion, Ideology, and Education in Hobbes's Leviathan," in Reclaiming the History of Ethics: Essays for John
} 
the sovereign's duty is to teach subjects to act in conformity to the law of sociability "not so much from fear of punishments as from habit (assuetudo)" ${ }^{50}$ While critiquing the Aristotelian notion of zoon politikon, Pufendorf nonetheless contended that in a more limited sense man can "be said to be by nature a political animal", because once political societies have been established "men become accustomed in them to live a decent civil life". ${ }^{51}$ Pufendorf follows Hobbes by advocating the sovereign's duty to educate his subjects to civil obedience. Yet, the important difference between the two philosophers is that, for Pufendorf, processes of socialisation and habituation in many cases lie (and ought to lie) outside of the sovereign's reach. In civil society, people learn to act sociably as a result of their iterative mutual interactions: a process that cannot be understood exclusively in terms of political governance. Justice is a necessary, but not sufficient condition for sociability, as Pufendorf observed:

It is not enough, however, not to have hurt another, or not to have deprived him of the esteem he is owed: These only remove the just cause for hatred. Something good must also be conferred on the other, at least if the minds of men are to be conjoined by a still closer bond. Someone who has not driven me away from himself by some hostile or ungrateful deed has not discharged the debt of sociality; rather, he should furnish something beneficial so that I am glad that others who share my nature also live upon this earth. And, as well, the affinity and kinship established among men by nature must be exercised by means of mutual duties..$^{52}$

Locke was animated by a similar concern, declaring that:

We must not content our selves with the narrow Measures of bare Justice. Charity, Bounty and Liberality must be added to it. This the Gospel enjoins; this Reason directs; and this that natural Fellowship we are born into requires of us. ${ }^{33}$

On Hobbes's account the law of nature only acquires the status of a law, the precepts of which are obligatory in performance rather than merely endeavour, when promulgated in the form of civil law. ${ }^{54}$ Concerned to secure peace, the magistrate necessarily focuses on the enforcement of justice: it is hard to see how, by means of civil penalties, men might be induced actively to do good to one another, rather than merely restrained from doing harm. As the above citation from

\footnotetext{
Rawls, ed. Andrews Reath, Barbara Herman, and Christine M. Korsgaard (Cambridge: Cambridge University Press, 1997), 32-65; Teresa M. Bajen, "Teaching the Leviathan: Thomas Hobbes on Education," Oxford Review of Education 36 (2010): 607-26.

${ }^{50}$ Pufendorf, De jure naturae et gentium 7.9.4/ Political Writings, 242.

${ }^{51}$ Ibid., 7.1.4/ 205.

${ }^{52}$ Ibid., 3.3.1/ 164-5; cf. Pufendorf, On the Duty of Man and Citizen, ed. James Tully and trans. Michael Silverthorne (Cambridge: Cambridge University Press, 1991), 1.8.1.

${ }^{53}$ Locke, Letter concerning Toleration, 20.

${ }^{54}$ Hobbes, Leviathan, 2.26, 418.
} 
Pufendorf indicates, a basic respect for one's fellow men as one's equals might be a prerequisite for justice; but it is the desire for preferential esteem from others that animates us to labour for their happiness. Here Pufendorf made an important distinction between two types of esteem: "simple" (existimatio simplex) and "intensive" (existimatio intensiva). ${ }^{55}$ In the domain of simple esteem, an act of recognition means considering the other as a good man who has some value in social life: it implies the right to be treated by others not as "a dog or beast, but as much a man as you". ${ }^{56}$ For "affinity and kinship" to be "established among men", however, a more generous and positive act in the realm of recognition - that of "intensive" esteem - is required. This involves the free acknowledgement of another as an individual who has exercised his will in ways the admirer deems worthy of admiration and praise. Pufendorf does not deny that some forms of intensive esteem, such as those signified by honorific titles or public office, will rely on the arbitrary decision of the sovereign. He is nonetheless concerned to create social space for a sphere of intensive estimation that relies on the voluntary judgements of men and lies outside of the jurisdiction of the sovereign. Unlike on Hobbes's interpretation, in seeking preferential esteem we have no choice but to accommodate ourselves to others' judgments of our value, rather than coerce others to accept our subjective (and inflated) sense of our own worth and merit. It follows that the quest for preferential esteem generates shared norms of propriety to which all men, desirous of esteem, recognise themselves to be beholden - rather than, as for Hobbes, precluding this possibility.

In labouring the point that preferential esteem cannot be coerced from others, Pufendorf explicitly identified Hobbes's treatment of honour in chapter 10 of Leviathan as his target. Due to our psychological make-up, “intensive esteem” only matters to us - it only gives us pleasure - to the extent that we recognize it to be sincere. "The mere external signs of honour", Pufendorf declared, "unless they arise from the submission of the mind, are empty things". This "submission of the mind" cannot be "forced from a man" even by "the power of sovereignty" and on pain of death. ${ }^{57}$ Whereas Hobbes had no problem basing practices of honour in fear, Pufendorf argued that coerced, insincere esteem is worthless: "things which may be extorted by force have no such power to win the hearts of others, as those which may be denied without fear". ${ }^{58}$ In any case, we are incapable of concealing the spontaneous sentiments we experience when judging and/or being judged by others, because blushing and other involuntary corporeal signs reveal our true

\footnotetext{
${ }^{55}$ For the distinction between simple esteem and intensive esteem, see Haara, Pufendorf's Theory of Sociability, 101-7.

56 Pufendorf, De jure naturae et gentium 3.2.1/ Political Writings, 159.

${ }^{57}$ Pufendorf, De Jure naturae et gentium 8.4.14/ Of the Law of Nature and Nations, 1249.

${ }^{58}$ Ibid., 3.4.6/ 386.
} 
sentiments. ${ }^{59}$ As Locke similarly observed, "the Physiognomy of the Mind" renders our sentiments legible to others, even if it is most transparent in children. ${ }^{60}$

Locke extended this logic into the realm of divine worship: for the "esteem" we profess in worship to be "pleasing unto God", it must express "the inward and full perswasion of the mind"; otherwise, through our "Hypocrisie" we exhibit a "Contempt for his Divine Majesty". ${ }^{11}$ The mere pretence of esteem, in religion as in civil life, frustrates the end we seek in offering it: the good opinion of others. We are all acutely sensitive, as Hobbes emphasized, to contempt, due to what Pufendorf termed the "very delicate" character of our "self-esteem" (sui estimatio), which leads us to desire affirmation from others. ${ }^{62}$ For Pufendorf, it is clear evidence of man's social nature that "every good man takes the greatest delight in distinguishing himself among his fellows by worthy deeds". ${ }^{63}$ As Locke observed, this "quick sence of Reputation" explains our acute sensitivity ("Tenderness") to others' opinions of our merit and worth - opinions that, try though they might, they cannot conceal or feign. ${ }^{64}$ As Locke reflected in his private journals, it was indisputable that the first question most men ask, "in all things he doth, or undertakes" is "how will this render me to my Company, and those, whose esteeme I value?". ${ }^{65}$ If the sovereign could, as Hobbes implied, to a great extent dictate to men the criteria by which they ought to esteem one another, then this would give him a remarkable power over his subjects. ${ }^{66}$ Yet the sovereign both lacked this power in practice, and any claim to it in theory: it was no part of his jurisdiction to impose upon men's consciences in the realms of either civil or divine esteem, because such imposition was unnecessary to secure the end (peace and security) for which authority had been entrusted to him. ${ }^{67}$

\footnotetext{
${ }^{59}$ Ibid., 1.2.7/ 32.

${ }^{60}$ Locke, Some Thoughts concerning Education, \$101, 206.

${ }^{61}$ Locke, A Letter concerning Toleration, 13. Pufendorf similarly condemns ambitious individuals who use confessional religious doctrines as a vehicle for political power and refuse to acknowledge that "all Men should allow to others their due Esteem, and not to prefer themselves before the World". Because the essence of true religion consists in the inward persuasion of the mind, it is contemptible to think that "God should be any Ways favourable to those who think fit to serve him in a different Manner": Samuel Pufendorf, The Divine Feudal Law: Or Covenants with Mankind, Represented, ed. Simone Zurbuchen (Indianapolis, IN: Liberty Fund, 2002), 12-13.

62 Pufendorf, De Jure Naturae et Gentium, 3.2.1; cf. Hobbes, Leviathan, 1.15, 234.

${ }^{63}$ Pufendorf, De Jure Naturae et Gentium, 2.3.15

${ }^{64}$ Locke, Some Thoughts concerning Education, $\$ 113,217$.

${ }^{65}$ Bodleian Library, MS Locke c.27, f.30r (1675).

${ }^{66}$ MS Locke f.3, 381-2 (12 Dec. 1678). Hobbes nonetheless acknowledged the limits to the sovereign's ability to dictate what is estimable or shameful, as indicated by his claim that patricide is always a cause of 'infamy and loathing', and individuals might legitimately refuse to perform such 'dishonourable' actions even when commanded to do so: Hobbes, De cive, 6.13, 83 .

${ }^{67}$ Locke's early Tracts on Government (1660-2) and Essays on the Law of Nature (ca.1663-4) are decidedly closer to Hobbes on this point. Just as "it is impossible for anyone to grow rich except at the expense of someone else" (ELN 211), so Locke seems to conceive of preferential esteem in similar terms.
} 
Aside from enforcing the rules of justice, for Locke men's consciences did not need to be constrained by political means in the moral realm, because they were already subject to discipline by alternative and more powerful constraints. As he noted in the Essay, civil law is strictly limited in both its coercive and imaginative efficacy: it cannot regulate men's conduct in private, nor can it compel them to behave in ways that exhibit much consideration for the wishes and needs of others. In the moral realm, it is the desire for esteem that (to borrow from Hobbes) forges "Unity" out of "Multitude" and creates a common will (law) to which all men recognize themselves beholden and not their mutual subjection to the sovereign. ${ }^{68}$ The pursuit of esteem habituates us into norms of propriety that are produced endogenously within societies on account of their communal utility. To secure esteem one must abide by these norms, encoded in what Locke called the "Law of Opinion or Reputation". It is this "Law" that regulates the realm of social morality and incentivizes men to perform their reciprocal 'imperfect' duties. As Locke declared, 'he who imagines Commendation and Disgrace, not to be strong Motives on Men, to accommodate themselves to the Opinions and Rules of those, with whom they converse, seems little skill'd in the Nature, or History of Mankind". ${ }^{69}$ Locke imposed a categorical distinction between the "Hobbist" (civil) law and the "Law of Reputation" due not merely to their different modes of operation, but to their discrete jurisdictions. The civil law promulgates and polices the negative ('perfect') duties of justice, whilst the "Law of Reputation" disseminates the positive ('imperfect') duties of social morality and enforces them with sanctions that are not physically coercive, and yet exercise the greatest power over men's minds: esteem and contempt. ${ }^{70}$ As Locke observed as early as 1675 , "Mankinde is supported in the ways of Vertue and Vice by the Society he is of, \& the Conversation he keeps; Example and Fashion being the great Governours of this Worlde". ${ }^{71}$

Insofar as the "Law of Reputation" issues from and is enforced by all members of society collectively, so it tends "to encourage with Esteem and Reputation that, wherein every one finds his Advantage; and to blame and discountenance the contrary". ${ }^{72}$ It encapsulates a corporate (or public) reason which can identify - as the subjective, self-loving individual could not - what is necessary for the collective well-being of all members of society. Viewed in this light, the desire for esteem has, so to speak, been hardwired into human nature by God, and for a purpose: to induce us to acknowledge what, in the opening pages of the Second Treatise, Locke calls our "Obligation to mutual Love". ${ }^{73}$ Our concern for esteem, as for Pufendorf, makes us inescapably interdependent

\footnotetext{
${ }^{68}$ Hobbes, Leviathan, 1.16, 248.

${ }^{69}$ Locke, Essay concerning Human Understanding, 2.28.12.

${ }^{70}$ Ibid., $1.3 .5 ; 2.28 .7-10$.

71 MS Locke c. 27, f.30r $(1675)$.

${ }^{72}$ Locke, Essay concerning Human Understanding, 2.28.11.

${ }^{73}$ John Locke, Two Treatises of Government, ed. Peter Laslett (Cambridge: Cambridge University Press, 1988), II: \$S5-6.
} 
creatures: we rely upon one another to secure the mental good that all of us recognize to be essential to our happiness. This brings the Golden Rule home to mankind, because what Pufendorf termed our "delicate self-esteem" - our self-love - is dependent upon the esteem and love of our neighbours: "If then happinesse be our interest end \& business, 'tis evident the way to it is to love our neighbour as our self, for by that means we enlarge \& secure our pleasures, since then all the good we doe to them redoubles upon our selves \& gives us an undecaying \& uninterrupted pleasure". ${ }^{74}$ This providential process is likely to be disturbed if the sovereign determines, as Hobbes decreed he ought, to interfere with the "Law of Reputation": it is for this reason that Locke advanced what he recognized to be the "strange" doctrine that the civil magistrate "hath nothing to do with moral virtues and vices", nor ought to "prescribe any rules about them, but leave them entirely to the discretion and consciences of his people". 75 "People" here assuredly means the collective body - society - and not every individual; and Locke's claim relies upon the conviction that such a "people" already have a "rule" to guide them to which they subject their individual wills: the "Law of Reputation". If left to operate as it ought, this "Law" will contain moral precepts that are likely to be consistent with those of natural law, given to man by God for their terrestrial wellbeing as well as His eternal glory. Since "nothing can be more natural, than to encourage with Esteem and Reputation that, wherein every one finds his Advantage; and to blame and discountenance the contrary: 'tis no Wonder, that Esteem and Discredit, Vertue and Vice, should in a great measure every-where correspond with the unchangeable Rule of Right and Wrong, which the Law of God hath established". ${ }^{76}$

On Locke's account, the "Law of Reputation" is generated prior to, as well as independent of civil law. This underpins Locke's claim in the Treatises that, contrary to Hobbes's assumption, men do have a rule to guide them in their natural condition: natural law, as discovered by men through their mutual interactions. This "Law" provides criteria by which to evaluate the merit of people and actions that are not subjective. Through processes of socialization and habituation, members of a society accept these criteria of good and ill as their own and evaluate their own actions, rather than merely those of others accordingly. There is no Hobbesian distinction between the internal and external forums here. Children, as Locke emphasized in his educational writings, might initially learn to act in particular ways because doing so wins them praise, but they will eventually do so because they consider such actions to be by their very nature good and obligatory. ${ }^{77}$ Insofar as the

\footnotetext{
${ }^{74}$ MS Locke c.42B, 224 (1692).

75 John Locke, “An Essay Concerning Toleration,” in John Locke: Political Writings, ed. David Wootton (Indianapolis, IN: Hackett Publishing Company, 2003), 195.

${ }^{76}$ Locke, Essay concerning Human Understanding, 2.28.11.

77 On which see Michelle E. Brady, "Locke's Thoughts on Reputation," The Review of Politics 75 (2013): 335-356.
} 
precepts of the "Law of Reputation" tend to be consistent with natural law, so they are also in harmony with the moral law contained in the Gospels: upon the reading of which men will discover the true foundation of all morality in God's will and command. If the sovereign interferes with the "Law of Reputation", he obstructs the social processes by which the individual is disciplined in such ways as render him a sociable, morally accountable creature, capable of government. This is why, in both the Essay and Treatises, Locke labours the point that individuals must be left at liberty to esteem one another as they see fit. In direct contradiction to Hobbes's theory (and, to some extent, Pufendorf's), for Locke we retain an inalienable right as members of communities collectively to define standards of moral good and ill. We also retain the right to punish transgressions of these moral norms. Even if we give up to the sovereign our natural right to employ coercive force to punish transgressions of natural law, we remain empowered to employ the (powerful) sanctions of esteem and contempt. Citizens "retain still the power of Thinking well or ill; approving or disapproving of the actions of those whom they live amongst, and converse with: And by this approbation and dislike they establish amongst themselves, what they will call Vertue and Vice."78

\section{Conclusion}

If Hobbes's solution to the problem of sociability was emphatically political in nature, he was nonetheless keenly aware that society generates other forces that shape and constrain the individual's appetites and desires in complex ways. Hobbes identified the desire for recognition as a primary reason why the individual is so susceptible to these currents; and he maintained that they might act on subjects in ways that reliably conduce to peace - the ultimate aim of Hobbes's political philosophy - only if harnessed and regulated by the sovereign. The sociability debate after Hobbes invites the thought that Hobbes's diagnosis of the problem was considered to be far more compelling, and convincing, than his solution to it.

Pufendorf and Locke, at least, appear to have held this view. They could agree with Hobbes that man is, by nature, animated by self-love, and that it is the desire to have this love affirmed by others (rather than natural benevolence) that induces him to seek society. They could similarly agree with Hobbes that self-love appears to preclude the possibility that individuals might voluntarily choose to benefit others unless they stand to gain by doing so. As Pufendorf observed, "not just anyone has such goodness of character as to be willing to do all the things by which he can benefit others out of humanity or charity alone, without a well-founded hope of receiving an

\footnotetext{
${ }^{78}$ Locke, An Essay concerning Human Understanding, 2.28.10.
} 
equivalent in return". ${ }^{79}$ Yet, for Locke and Pufendorf, there is an "equivalent" that attends such other-regarding conduct: the reward of esteem, the most pleasing "good" of all. Such esteem, contrary to Hobbes's claims, cannot be extorted from others by force or fraud: it must be earned, by acting in ways that appear meritorious to the esteem-giver. The desire for esteem makes men inherently interdependent creatures. The mental good they consider to be most essential to their happiness - esteem - requires them to treat others as they would be treated: to love their neighbour as they love themselves. Pufendorf and Locke made no effort to rehabilitate the doctrine of natural benevolence, as Francis Hutcheson would later; instead, they endeavoured to show that self-love can, and must, give rise to friendships characterized by mutual equality and reciprocity. Only thus might we self-loving creatures secure the end - the esteem and love of others - that we seek in entering society.

For Locke and Pufendorf, then, a broadly Hobbesian anthropology demanded not a denial of the very possibility that men are capable of sincere friendship and "mutual Love", but rather a new purportedly (non-Aristotelian) explanation of how they become such creatures in the course of their iterative mutual interactions in society. This process, as Locke's writings show most clearly, remains contingent: the criteria by which we learn to evaluate the merit and worth of actions and characters (ourselves included) might all too easily become corrupted in pathological societies. If citizens are encouraged to value one another on the basis of their speculative opinions in religion rather than their moral conduct (as in intolerant "Christian commonwealths"), or to mistake material for moral worth (in advanced commercial societies), the harmony between social esteem and moral performance will assuredly be disturbed. But the cause of any such corruption would need to be found in defective social and political institutions, and not - as Hobbes was held to maintain - in human nature itself. This insight was further developed in the eighteenth century by those philosophers, such as Hume and Smith, who foregrounded the importance of processes of socialization and habituation in the development of the moral personality.

${ }^{79}$ Pufendorf, De jure naturae et gentium, 3.4.1/ Political Writings, 166. 